\title{
Е.Н. Наземцева
}

\section{СОВЕТСКОЕ ГРАЖДАНСТВО КАК ФАКТОР БЕСПРАВИЯ? ПРОБЛЕМЫ ПОЛИТИКО-ПРАВОВОГО ПОЛОЖЕНИЯ СОВЕТСКИХ ГРАЖДАН В СИНЬЦЗЯНЕ ВО ВТОРОЙ ПОЛОВИНЕ 1920-х гГ.}

\begin{abstract}
Рассматриваются проблемы политико-правового положения советских граждан и бывших подданных Российской империи, получивших советское гражданство во второй половине 1920-х гг., их влияние на советско-китайские отношения в центральноазиатском регионе. Особое внимание уделено деятельности советских консулов в Синьцзяне по защите прав советских граждан и русских эмигрантов, желающих получить советское гражданство, взаимодействию консулов с руководством провинции и НКИД СССР

Ключевые слова: русская эмиграция; советские граждане; Синьцзян.
\end{abstract}

Проблемы политического и социального положения советских граждан в Китае в 1920-1940-е гг. получили освещение в научных исследованиях лишь недавно. Однако в основном внимание ученых традиционно сосредоточено на изучении советской колонии в Маньчжурии. Лишь некоторые исследователи уделяли внимание положению советских граждан в других провинциях Китая [1-3]. Изучение советской колонии в крупнейшей провинции Китая - Синьцзяне - из-за практически полностью закрытых источников пока остается неисследованной темой. Между тем она здесь была довольно многочисленной. Ее представляли как бывшие подданные Российской империи и русские эмигранты, принявшие советское гражданство, так и советские служащие, прибывшие в Синьцзян в 1920-е гг. для работы в консульствах и на различных предприятиях.

Влияние СССР в Синьцзяне в этот период было довольно значительным. Это касалось как внешнеполитических, так и экономических аспектов. Уже в мае 1920 г. были возобновлены торговые контакты между Синьцзяном и Советской Россией. К моменту установления официальных межгосударственных взаимоотношений между Китаем и СССР два сопредельных государства уже четыре года вели здесь активную торговлю. Даже после разрыва отношений между СССР и Китаем в 1927 и 1929 гг. в провинции продолжали функционировать советские консульства, равно как и китайские в Средней Азии и Казахстане. Продолжалась и двусторонняя торговля [4. С. 451]. Укреплению советских позиций способствовала и постройка в 1929-1932 гг. Туркестано-Сибирской железной дороги [5. С. 78].

Этому благоприятствовала и внутриполитическая обстановка в провинции: ослабление китайских позиций и рост влияния мусульманских кругов. Нанкин не имел возможности оказывать влияние на ситуацию. Единственным выходом для местной администрации стало сотрудничество с советскими представителями, которые могли оказать политическую и военную помощь. Однако не все в администрации губернатора Синьцзяна Ян Цзенсиня разделяли эту линию. Некоторые выступали за ориентацию на Нанкин. Тесное сотрудничество вызывало у них опасения за суверенитет провинции. Это, в свою очередь, приводило к ухудшению политического и правового положения рядовых советских граждан, а также тех, кто недавно получил или собирался получить советский паспорт.

29 июня 1925 г. Коллегией НКИД было принято согласованное с ОГПУ предложение экономико-правового отдела НКИД «О предоставлении консулам в Западном Китае особых прав по оформлению гражданства» [6. Л. 18]. Бывших российских граждан - купцов и духовенство, являвшихся мусульманами, «в связи с выяснившимся благожелательным настроением» Коллегия НКИД с согласия ИНО ОГПУ разрешила восстанавливать в гражданстве без запроса центра [7. Л. 5]. Кроме того, советским консулам в Западном Китае было предоставлено право одновременно и амнистировать на месте бывших рядовых солдат и казаков, и сразу же выдавать им местные визы на въезд в СССР, учитывая, что в отношении амнистированных возможны репрессии со стороны местных китайских властей. К тому же отдел Среднего Востока был против разделения вопросов о применении амнистии и выдаче виз на въезд. Это объяснялось тем, что раздельное решение вопроса об амнистии и визах могло привести к тому, что в Западном Китае окажутся советские граждане с советскими паспортами, въезд которых в СССР мог быть признан в центре недопустимым. В то же время консулам было предписано амнистировать лишь тех лиц, которые были хорошо известны, «как заслуживающие применения акта об амнистии». Для тех бывших рядовых солдат и казаков, в отношении которых у консульств имелись малейшие сомнения, применение амнистии и разрешение въезда в СССР должны были проводиться через центр [8. Л. 22].

Тем не менее расширение прав консулов в Западном Китае не способствовало решению вопросов о регистрации бывших русских граждан и эмигрантов, так как по имеющимся у советских властей данным консульствам чинились всевозможные препятствия. Например, 
8 августа 1926 г. консульство СССР в Чугучаке обратилось к местному даоиню с просьбой о разрешении регистрации и содействии в проведении учета бывших русских граждан, желающих получить советское гражданство, а также разрешении расклеить объявление о регистрации. Но в ответном письме даоиня просьба консульства была отклонена. Следующим письмом на имя даоиня консульство, оспаривая его доводы, указывало, что китайские консулы в СССР оповещают свободное свое население не только объявлениями, но и через прессу [9. Л. 33]. Однако это снова не возымело действия.

Среди примеров притеснений советских граждан были и запреты переезжать из одного города в другой, и произвольные выселения из пределов Китая, и аресты, «производимые в целях устрашения и достижения определенных домогательств, и принуждения к исполнению различного рода работ (в большинстве случаев они выражались в требованиях предоставления бесплатно или за весьма мизерное вознаграждение подвод для обслуживания китайских чиновников). При отказах от исполнения советские граждане подвергались избиениям. Широко практиковалось и оставление китайскими властями без наказания уголовных преступлений убийств, грабежей, насилий, совершаемых в отношении граждан СССР, даже в тех случаях, когда советские консульства сообщали синьцзянским властям все данные, необходимые для арестов преступников [Там же. Л. 3].

В консульства поступало огромное количество сообщений об открытии китайскими властями чуть ли не похода против советских граждан, вплоть до того, что распускались слухи об их выселении из городов, в которых отсутствовали советские консульства, и вселении в города пребывания консульств. Анализируя обстановку, советские представители пришли к выводу о неслучайности репрессий китайских властей по отношению к советским гражданам, тем более что гонения принимали организованный характер [Там же. Л. 11-12]. В 1927-1928 гг. китайские власти усилили репрессивные меры по отношению к советским гражданам: при переезде их из одного города в другой требовали специальный пропуск, на письма консульства о выдаче таких пропусков отвечали, что это исключительно их дело; советским гражданам была запрещена торговля в тех городах, где отсутствовали советские представители. Местные налоги снимались с совграждан на 90\% больше, чем с китайцев.

Вызывало недовольство советской стороны и правовое положение русских женщин в провинции, в особенности в приграничной полосе. По мнению консулов, оно было «исключительно тяжелое». Это объяснялось тем, что, выходя замуж за китайцев, женщина, по мнению китайских властей, теряла советское гражданство и становилась бесправным объектом эксплуатации мужа. Выходили же замуж женщины за китайцев из-за бедности, «обрекая себя на вечное рабство». В связи с этим советское консульство считало, что «вопрос о правовом положении русских женщин-согражданок, вышедших замуж за китайцев, не может не остановить на себе нашего самого серьезного внимания» [Там же. Л. 74].

Спорным оказывалось и положение тех женщин, которые регистрировали свой брак с белогвардейцами. Согласно указаниям заведующего отделом Среднего Востока В.М. Цукермана, не следовало «чинить препятствия и отказывать в регистрации брака в том случае, если данный белогвардеец не является особенно злостным и особенно сильно проявившим свое антисоветское настроение». Однако Генеральное консульство затруднялось «в выборе критерия, которым оно могло бы руководствоваться в деле определения степени антисоветскости того или иного белогвардейца, тем более что сам факт нерегистрации белогвардейца до сего времени уже, казалось бы, в достаточно степени свидетельствует о его отношении к соввласти», и просило на этот счет специальных указаний [Там же. Л. 15].

Одной из особенностей обстановки в Синьцзяне являлось то обстоятельство, что лица, подавшие заявление о восстановлении их в совгражданстве, рассматривались китайскими властями уже как совграждане с соответствующими отсюда выводами правового и юридического характера. Это толкало последних по целому ряду случаев искать помощи в советском консульстве, которое на основе существующих циркуляров этой помощи им оказывать не имело права, ибо они еще не являлись совгражданами. Некоторые зарегистрированные обращались в Генеральное консульство с просьбами о регистрации браков, разводов, рождений, руководствуясь в данном случае соображениями легализации гражданского состояния на случай возвращения в СССР [Там же. Л. 15].

Особое недовольство советской стороны вызывал вопрос защиты прав советских граждан в провинциальных судах, так как китайцы, пользуясь отказом от консульской юрисдикции, судили советских граждан не по европейским законам, как это предполагала советская сторона при отказе от юрисдикции, а по кодексу дайцинской династии, а так как в Синьцзяне вообще не было специального судебного органа и законов, то часто судили уездные начальники. На протяжении второй половины 1920-х гг. не было случая, когда бы дело в суде, будь оно гражданского или уголовного характера, если одной стороной выступал совгражданин, а другой китаец, было решено в пользу совгражданина; при этом в большинстве случаев все обстоятельства дела с полной несомненностью говорили в пользу последних [Там же. Л. 13]. Все это приводило к тому, что те русские, которые хотели бы получить совгражданство, старались перейти в китподданство [9. Л. 78]. Началась паника и в советской колонии.

Консулы оказывались фактически бессильными в защите прав советских граждан. Каждый раз, когда по какому-нибудь конкретному случаю консульства обращали внимание китайских властей на недопустимое отношение к советским гражданам, от китайских властей 
следовал один и тот же ответ, что «выступления консульств нарушают китайский суверенитет, противоречат международному праву и что вообще консульства не должны принимать жалобы от советских граждан, так как этим нарушается отказ Правительства СССР от консульской юрисдикции и прав экстерриториальности, предусмотренных советско-китайским соглашением от 31 мая 1924 г.» [9. Л. 2].

Консулы СССР считали, что необходимо принять соответствующие меры для облегчения жизни советских граждан и указать китайским властям на то, что «нельзя ставить советских граждан на ступень бесправных рабов, поставленных в такое положение исключительно потому, что они советские граждане, в то время когда так называемые «международные граждане» белогвардейцы - пользуются всеми правами и преимуществами» [Там же. Л. 12]. Консул в Чугучаке видел причину этого в слишком мягкой политике по отношению к Китаю вообще и китайцам в СССР в частности: «...до сих пор мы все это беззаконие пропускали безнаказанно для китайцев и никаких репрессий как внутри СССР, так и здесь не принимали... мы к разрешению таких вопросов подходим слишком мягко», - и предлагал создать такую обстановку для китайских властей, «которая заставила бы их слушаться и уважать наши законы, так же как мы обещали уважать их законы в пекинском соглашении» [Там же. Л. 78-79].

В конце концов советские представители вынуждены были направить в НКИД просьбу обратить серьезное внимание на положение дела защиты советских граждан, «так как в результате бессилия консульств против чинимого синьцзянскими властями террора и произвола в среде местного населения граждан СССР возникают недоброжелательные к консульствам настроения». Кроме того, консульства считали необходимым сделать специальное представление центральным властям Синьцзяна, для чего Коллегии НКИД предоставили проект специального меморандума [Там же. Л. 5].

НКИД предложил ввести институт аксакалов из советских граждан, которые могли бы выступать во всех китайских учреждениях для защиты интересов граждан СССР. Однако консулы в Синьцзяне были против этого. Они объясняли свою позицию тем, что если официальные консульства в своих выступлениях перед китайскими властями не в состоянии влиять на них для вынесения правильного решения, а с китайской стороны всегда следовали «демагогические письма со ссылками на Пекинское соглашение, отказ от юрисдикции и т.п.», то тем более влияние не смогут осуществить аксакалы, уже не говоря о том, что они, по мнению консулов, также подвергались бы всевозможным притеснениям со стороны китайцев, и консулам пришлось бы выступать перед китайцами в их защиту. Кроме того, по мнению консулов, китайские власти не допустили бы организации института аксакалов и рассматривали бы попытки к его созданию как нарушение суверенитета и укрепление СССР в провинции. Это, в свою очередь, могло усилить, с одной стороны, репрессии против советских граждан вообще, а с другой еще больше помешать работе по оформлению советского гражданства бывшим российским подданным, которых еще не успели восстановить. Восстановленных же пока было не более 20-25\% «всего имеющегося в Синьцзяне количества». Поэтому вопрос об аксакалах предлагалось оставить открытым, а вплотную подойти к созданию в Синьцзяне сильной советской колонии [Там же. Л. 13].

Доводом против создания в Синьцзяне института аксакалов служило и то соображение, что, по мнению советских представителей, «если китайцы даже и согласятся на создание института аксакалов, то они, безусловно, потребуют создания аналогичного института для китграждан внутри СССР», но «разница между нашими и китайскими аксакалами будет заключаться в том, что наши аксакалы будут подвергаться в Синьцзяне всевозможным гонениям, а китайские аксакалы в СССР будут заниматься демагогией и мешать соответственному подходу со стороны соввластей к китгражданам» [Там же. Л. 14].

Кроме того, случаи разрешения того или иного дела в пользу советских граждан часто объяснялись неустойчивостью положения дудзюня, когда по соображениям политического характера он был вынужден идти на уступки советским консулам и требовать того же от даоиней, а при укреплении своего положения игнорировал представления советской стороны. Не желая ставить интересы советских граждан в зависимость от колебаний положения дудзюня, советские консулы настаивали на необходимости «выступить в Синьцзяне единым фронтом» и требовать от китайских властей применения к советским гражданам европейских методов судебно-следственной процедуры, имея в виду, что и п. 7 Пекинского соглашения гласил, что СССР согласен отказаться от консульской юрисдикции лишь при условии, что в Китае к совгражданам будут применяться приемлемые для нас судебно-следственные методы [Там же. Л. 13].

В результате на специальном совещании экономическо-правового отдела НКИД по синьцзянским вопросам было принято решение поручить отделу Среднего Востока и 2-му отделу частного права экономико-правового отдела составить проект меморандума для вручения синьцзянским центральным властям, выработать проект реторсий по отношению к синьцзянским гражданам в СССР, поручить 2-му отделу направить консулам СССР в Синьцзян инструкцию о порядке информирования центра по вопросам правового положения граждан СССР в Синьцзяне [9. Л. 7]. Кроме того, было принято решение установить максимально сокращенный порядок для прохождения дел о восстановлении в советском гражданстве лиц из Синьцзяна, «ввиду специфических условий этой провинции», а также разрешить консулам СССР оказывать содействие лицам, подавшим заявления о восстановлении их в советском 
гражданстве, еще до их восстановления в таковом «ввиду длительности срока прохождения этих дел и в случаях, если консул имеет основание полагать, что данному лицу не будет отказано в восстановлении» [9. Л. 8].

Отношение китайского руководства к советским гражданам и проведению регистрации русских эмигрантов и бывших российских подданных демонстрировала ситуация, сложившаяся в Кашгарском округе провинции.

Бывших русско-подданных здесь было довольно много. Еще в 1914 г. представителем русского консульства В.М. Федоровым совместно с Уполномоченным китайскими властями чиновником И Цзе была проведена регистрация всех российских подданных Кашгарского консульского округа, и после детального выяснения вопросов подданства был составлен полный список глав семей русско-подданных, скрепленный подписями и печатями русского и китайского представителей. Было зарегистрировано 2312 семейств (из отчета российского консульства за 1915 г.) [10. Л. 1]. Сверх того было еще зарегистрировано 174 семейства, не вошедших в списки по аксакальствам. Всего же в Кашгаре проживали свыше 10000 бывших русско-подданных [Там же. Л. 9]. Кроме того, в Кашгарском округе имелось 24 аксакальства, и только по 13 южным аксакальствам было точно установлено количество земли, принадлежащей русско-подданным. Таким образом, русско-подданным только в южной части Кашгарии принадлежало 4500 десятин земли, что при местном земельном голоде являлось весьма внушительной цифрой [Там же. Л. 2].

Китайское правительство с первого года республиканского строя решительно боролось с иностранным землевладением в Китае, и в частности в Кашгарии, но вследствие не менее решительных контрдействий русского и английского консульств русские и английские подданные вплоть до Первой мировой войны не только сохраняли здесь земельную собственность, но и продолжали ее увеличивать покупкой и самовольными захватами у китайских подданных. Мировая война ослабила влияние русских и англичан в Синьцзяне, что сразу проявилось в возникновении непрерывных земельных конфликтов между консульствами - английским и русским - с одной стороны и китайским властями - с другой. К моменту открытия в Кашгаре советского консульства в 1925 г. окончательно определилось следующее положение: китайские власти сохранили земельную собственность за английскими старожилами и бывшими русско-подданными, лишив возможности дальнейшего округления землевладения прикупкой земли у китайских подданных. Оказывая противодействие образованию советских колоний в Кашгарии из бывших российских подданных, кашгарский даотай Ма в переписке с советским Генеральным консулом в Кашгаре М.Ф. Думписом истолковал регистрацию русско-подданных в советском гражданстве как переход из одного подданства в другое. В своем письме от 28 июля 1927 г. № 13 Ма писал Думпису: «Вопрос относительно бывших российских подданных, проживающих на китайской территории, разбирался в прошлом году между Полномочным Представителем СССР господином Караханом и Китайским Министерством Иностранных Дел в Пекине. И тогда г[осподи]н Карахан заявил, что лица, не зарегистрированные в советских представительствах, хотя имеющие в прошлом какие-либо заслуги, не считаются больше российскими подданными и не принимаются в советское подданство. Следовательно, лица, проживающие на китайской территории и не имеющие своей родины, подчиняются китайским законам и пользуются полным покровительством китайских властей, и когда они захотят принять какое-либо подданство, то должны сперва заявить об этом китайским властям... Представители Китайской Республики в советских городах выдают своим подданным документы на право временного проживания в таковых, но они совершенно не предпринимают конкретных шагов к тому, чтобы принять в китайское подданство лиц, не имеющих родины, и не просят представителей СССР помогать им в этом деле. Мне известно, что в Алтае, Чугучаке и Кульдже советские представители посылали своих секретарей по городу уговаривать людей принимать советское подданство и даже расклеивали объявления. Когда это стало известно китайским властям, то последние перестали дружески посещать советских представителей» [Там же. Л. 3-4].

Таким образом, Ма, с одной стороны, признал советское правительство, добровольно отказавшееся от всяких прав на бывших российских подданных в Кашгаре, a c другой - фактически опротестовывал производившуюся в Шара-Сумэ, Чугучаке и Кульдже регистрацию советских граждан. Ма считал, что если бывшие российские подданные желали принять советское подданство, то они должны прежде всего явиться к китайским властям и заявить им об этом, а также предоставить точные сведения о размерах имеющегося у них недвижимого имущества [Там же. Л. 4]. И «если не встретится никаких препятствий к этому», то даотай должен сообщить генерал-губернатору провинции, а тот - в Пекин. Только после того, как Пекин санкционирует этот вопрос, советскому генеральному консулу будет разрешено принимать бывших российских подданных в советское гражданство [Там же. Л. 4].

Тем не менее М.Ф. Думпис продолжил проводить регистрацию бывших российских подданных, но делал это более осторожно, стараясь не вызывать недовольства и подозрения китайских властей. Так, восстановив в советском гражданстве 19 человек, он передал паспорта на согласование кашгарскому даотаю, однако последний отказался вернуть их. Назначенный в 1928 г. новый Генеральный консул СССР в Кашгаре Б.П. Постников направил письмо в Урумчи Генеральному консулу Л.М. Гавро, чтобы он добился от губернатора Синьцзяна распоряжения кашгарскому даотаю о выдаче 19 бывшим российским подданным, восстановленным 
в советском гражданстве советских паспортов, переданных на согласование кашгарскому даотаю. Однако Гавро считал, что Думпису вообще не следовало передавать паспорта китайским властям, а нужно было вручить их непосредственно вновь зарегистрированным советским гражданам. В создавшейся же обстановке он полагал, что необходимо вновь заготовить 19 паспортов и выдать их совгражданам, чтобы избежать прецедента [10. Л. 5].Постников же остался на стороне Думписа и, изучив старый архив консульства, пришел к выводу, что точь-в-точь как рекомендовал поступить Гавро, действовал в 1910-1914 гг. Генеральный консул Российской империи в Кашгаре С.В. Соков, «раздававший по своему усмотрению, не спрашивая согласия китайских властей тун шанпяо, следствием чего были повсеместные погромы русских колоний в Кашгарии». Но, как справедливо отмечал Постников, «тогда Соков мог для защиты русско-подданных и своего престижа опереться на специально вызванный сильный экспедиционный отряд», в новой же обстановке такая крайняя мера «является абсолютно исключенной» [Там же. Л. 5]. Тем не менее паспорта все же были возвращены даотаем консульству [Там же. Л. 43].

Постников указывал на другие меры противодействия китайских властей регистрации в советском гражданстве бывших российских подданных, например угрозу конфискации недвижимого имущества зарегистрировавшихся с принудительной высылкой их в СССР. Однако так как сохранение за англоподданными-старожилами права владения недвижимостью отнюдь не вытекало из договорных соглашений о капитуляциях, то ссылка на это положение была, по мнению консула, достаточной для противодействия китайской аргументации, настаивающей на лишении советских граждан не только владения имуществом, но и права постоянного жительства на территории Кашгарии. Кроме того, упоминание о возможности выселения на основе взаимности китайских подданных - уйгур - из советского Туркестана обратно в Синьцзян также «было бы весьма полезным». По мнению Постникова, китайцы, абсолютно равнодушные к материальному положению своих подданных уйгур находящихся в СССР, «весьма встревожатся при мысли о принесении ими в Синьцзян советской заразы» [Там же. Л. 6].

Регистрация бывших российских подданных действительно рассматривалась советскими представителями в провинции, в особенности в Кашгаре, как одно из средств советской разведки. В частности, еще М.Ф. Думпис предлагал открыть в г. Таш-Кургане консульское агентство для наблюдательной деятельности в сторону Индии (Гильгитское направление), так как, по разным сведениям, в данном районе имели место интенсивная работа Англии «по устройству военной коммуникации и скопление англо-индийских войск в Гильгитском направлении» [Там же. Л. 9]. Однако прибывший в Кашгар Постников был против открытия такого агентства до достижения соглашения с китайской стороной относительно восстановления в советском гражданстве бывших российских подданных, обосновывая это тем, что только после того, как в Кашгарии появятся советские граждане, уместно будет начинать с китайскими властями переговоры о дополнительном консульском учреждении в Кашгаре, а именно в ТашКургане [Там же]. В то же время он понимал необходимость иметь в пределах Кашгарского округа, особенно на границах с Индией, Тибетом и Ганьсу, «хотя бы несколько десятков признанных советских граждан - постоянных жителей тех мест», так как только при их наличии консульство успешно могло бы «протянуть свои наблюдательные щупальца к важнейшим очагам политики Центральной Азии», поэтому призывал применить все возможные рычаги воздействия на синьцзянское правительство [Там же. Л. 6].

Из-за позиции китайских властей бывшие русскоподданные в Кашгаре не стремились получить советское гражданство, так как небезосновательно опасались репрессий с их стороны. Например, в мае 1928 г. в Файбазане произошла драка между китайскими подданными и бывшими русско-подданными, не принявшими еще советского гражданства. Бывшие русско-подданные, пожаловавшиеся на это уездному начальнику, были посажены в тюрьму. На словесный протест генерального консула СССР даоинь кашгарского округа Ма возразил, что советское консульство не имеет никакого отношения к бывшим русско-подданным, так как они не являются советскими гражданами [Там же. Л. 43].

Другой случай произошел во время одной из поездок генконсула Постникова по округу. Он, в частности, отмечал, что при его проезде через селение Янгигисар все проживавшие там бывшие русско-подданные «поудирали из города, опасаясь, что если я вызову их к себе, то их накажут китайцы, если же они не явятся ко мне по моему вызову, то им попадет от меня». В Яркенде на следующий день после приезда советского консула группа купцов, бывших русско-подданных, явилась к уездному начальнику перезаверять свое китайское подданство, «дабы не подумали о них чего плохого». От бывшего российского аксакала Мулла-Ахуна Постников узнал о том, что почти все бывшие русскоподданные Яркендского уезда приняли китайское подданство под давлением со стороны китайских властей: бывших русско-подданных заковывали в цепи, конфисковывали имущество и т.п., наиболее тяжко пострадавшие от преследований погибли в тюрьме [Там же. Л. 27].

В результате Постников во время своей поездки старался не контактировать с бывшими русско-подданными, пытаясь тем самым заверить китайские власти в безобидности своих намерений, так как даоинь Ма действительно опасался возникновения волнений населения из-за производства их регистрации [Там же. Л. 28]. Кроме того, сам Постников даже рекомендовал всем, обращающимся к нему, «пока ограничиться сохранением своего сравнительно выигрышного положения “николаевских подданных” до того момента когда будет 
объявлено о регистрации» [10. Л. 29]. Тем не менее во время своей поездки Постников в течение первых трех дней выдал 27 советских паспортов, однако из-за отношения китайских властей дальнейшую выдачу паспортов все же приостановил. В то же время он попросил НКИД поставить в Урумчи вопрос о ситуации с регистрацией бывших русских подданных в Кашгарском округе «в полном объеме» [Там же. Л. 66].

Учитывая сложившуюся ситуацию, НКИД рекомендовал в беседах с Ма подчеркивать, что ни в одной стране власти не ставили препятствий СССР в проведении регистрации, объявления советских представительств о регистрации помещались в газетах и т.д., развеять подозрения Ма в якобы стремлении советских представительств создать революционные очаги в Кашгарии из восстановленных в советском гражданстве бывших русско-подданных, убедить даоиня в том, что советские власти восстанавливают в советском гражданстве лишь тех из бывших русско-подданных, кто имел «бесспорные доказательства принадлежности к российскому подданству» и «кто добровольно, без всякого принуждения» просил о восстановлении [Там же. Л. 57]. В случае продолжения противодействия Постникову рекомендовалось прервать свою поездку и возвратиться в Кашгар. В то же время НКИД требовал довести дело регистрации до конца, обеспечив ее нормальное проведение [Там же. Л. 58], для чего Генконсулу СССР в Урумчи НКИДом было направлено соответствующее письмо с приказом настаивать перед дудзюнем на том, чтобы кашгарские власти не чинили препятствий проведению регистрации в Кашгарии, а также указать дудзюню, что «постоянные уверения урумчинских властей в дружбе и добрососедских с СССР отношениях несовместимы с таким фактом, как отношение администрации даоиня Ма к б[ывшим] росс[ийским] гражданам» [Там же. Л. 56].

Постников предлагал пойти на компромисс, ограничившись легализацией советского гражданства не всей десятитысячной массы, а нескольких сотен, чтобы таким образом хоть как-то обеспечить наличие постоянного советского элемента на границах Индии и Тибета. Отказ же от восстановления в советском гражданстве большинства бывших русско-подданных он предлагал мотивировать перед китайскими властями тем, что СССР стремился «ликвидировать наследие русификаторской политики Царского Правительства в Синьцзяне, оставив советское гражданство лишь за действительными выходцами с территории Царской России, сохранившими доныне родственную или имущественную связь с Родиной» [Там же. Л. 67]. Если же «упорство» китайских властей преодолеть не удастся, то вопрос о регистрации бывших русско-подданных в Кашгаре предполагалось использовать как противовес претензиям китайских властей в политических или экономических переговоpax, тем более что обстановка политического замешательства в Синьцзяне после убийства губернатора Ян Цзенсиня благоприятствовала этому [Там же. Л. 67].

Подобное отношение к вопросу регистрации в советском гражданстве наблюдалось не только в Кашгарском округе, аналогичное положение сложилось и в других округах Синьцзяна. При этом высшие китайские чиновники упорно настаивали на срочном принятии советскими властями решительных мер к радикальному смягчению советского торгового и пограничного режимов в применении к китайским подданным [Там же. Л. 68].

Тем не менее непримиримая позиция китайских властей в Кашгарии все же заставила советское консульство признать регистрацию советских граждан фактически открыто сорванной китайскими властями [Там же. Л. 51].

Таким образом, несмотря на установление советскокитайских отношений, положение советских граждан и получивших советское гражданство бывших подданных Российской империи во второй половине 1920-х гг. было достаточно сложным. Причина этого заключалась в неоднозначном отношении китайских властей к укреплению в Синьцзяне позиций Советского Союза. Вместе с тем попытки советских консулов защитить советских граждан оказались практически безрезультатными. Обращения же в НКИД также не приводили к изменению ситуации, что было закономерно, так как советское руководство не считало необходимым открыто заявлять о данной проблеме, опасаясь, с одной стороны, широкой огласки своего укрепления в Западном Китае, а с другой - ослабления позиций из-за возможного скандала. В результате приоритет внешнеполитических интересов советского руководства приводил к уязвимости и противоречивости политико-правового положения советских граждан в Синьцзяне.

\section{ПРИМЕЧАНИЯ}

\footnotetext{
${ }^{1}$ Даоинь - начальник города или области.

${ }^{2}$ Кодекс дайцинской династии (1644-1911) - Да цинлуй ли, т.е. законы дайцинской династии и дополнения к ним, воспроизведенные из кодекса предшествовавшей минской династии (1368-1644).

3 Дуцзюнь - прежнее название губернаторов в Китае, державших в своих руках гражданскую и военную власть.

${ }^{4}$ Консульская юрисдикция - судебная власть консулов над своими соотечественниками на иностранной территории.

5 Реторсии (позднелат. Retosio - обратное действие) - предусмотренные международным правом ограничительные меры, предпринимаемые государством в ответ на аналогичные действия другого государства, наносящие экономический или моральный ущерб другому государству, например ограничение прав иностранцев, повышение таможенных пошлин. Являются ответом на правомерные действия другого государства, должны быть пропорциональны вызвавшему их акту и прекращаются с момента восстановления прежнего положения. Не предусматривают применения вооруженной силы или угрозы ее применения.

${ }^{6}$ Аксакальство - административная единица округа. Во главе аксакальства стоял аксакал, объединявший административную и политическую власть.

7 Даотай - начальник округа или области.

${ }^{8}$ Билеты, служившие удостоверением русского подданства.
} 


\section{ЛИТЕРАТУРА}

1. Аблажей Н.Н. С востока на восток: российская эмиграция в Китае. Новосибирск, 2007.

2. Кротова М.В. СССР и российская эмиграция в Маньчжурии (1920-1930-е гг.). СПб., 2014.

3. Яхимович С.Ю. Советские граждане в Северной Маньчжурии (1924-1935 гг.). Хабаровск, 2015.

4. Воскресенский А.Д. Китай и Россия в Евразии: историческая динамика политических взаимовлияний. М., 2004.

5. Противостояние : очерки военно-политической конфронтации первой половины ХХ века. М., 1995.

6. Архив внешней политики Российской Федерации (АВП РФ). Ф. 0253. Оп. 1. П. 1. Д. 1.

7. Центральный архив ФСБ России (ЦА ФСБ России). Ф. 2. Оп. 4. Д. 408.

8. АВП РФ. Ф. 054. Оп. 4. П. 275. Д. 4007.

9. АВП РФ. Ф. 054. ОП. 5. П. 300. Д. 5036.

10. АВП РФ. Ф. 0100 . ОП. 12. П. 153. Д. 59.

Nazemtseva Elena N. Military History Research Institute Military Academy of General Staff, Russian Armed Forces Moscow, Russia). E-mail: elenanazz@mail.ru

SOVIET CITIZENSHIP AS FACTOR OF ILLEGALITY? THE PROBLEMS OF THE POLITICAL AND LAW STATUS OF SOVIET CITIZENS IN XINJIANG IN THE SECOND HALF OF THE 1920s

Keywords: Russian emigration; USSR; Republic of China.

The aims of the article are to study the problems of the political and law status of Soviet citizens and former subjects of the Russian Empire who received Soviet citizenship in the second half of the 1920s, to determine their influence on Soviet-Chinese relations in the Central Asian region. The study is based on the service and administrative documentation of the People's Commissariat for Foreign Affairs (PCFA) and the Foreign Department of the United State Political Service of the USSR and personal correspondence of Soviet consuls from the Foreign Policy Archive of the Russian Federation and the Central Archive of the Federal Security Service. The article also describes the historiography of the problem.

The strengthening of the political and economic influence of the USSR in Xinjiang in the 1920s had conflicting consequences. A significant part of the political circles of Xinjiang, in particular, the heads of districts, opposed it, as feared for the sovereignty of the province. This led to a deterioration in the political and law status of ordinary Soviet citizens, as well as those who recently received or were about to receive a Soviet passport. Expansion of the rights of Soviet consuls, registration of former subjects of the Russian Empire and Russian emigrants, registration of those wishing to soviet citizenship could not change the situation. Soviet citizens were forbidden to trade, moved from city to city, they were charged with increased taxes, they were evicted from China, forced to perform various kinds of work, many were beaten, arrested and even executed. Attempts by Soviet consuls to protect the rights of Soviet citizens were not successful.

Thus, despite the establishment of Soviet-Chinese relations, the position of Soviet citizens in the second half of the 1920s was difficult. The reasons for this were the ambiguous attitude of the Chinese authorities towards strengthening the position of the Soviet Union in Xinjiang, as well as the lack of necessary law norms in China in general and in Xinjiang in particular to regulate the status of Soviet citizens. An important reason was the refusal of the Soviet leadership from consular jurisdiction in China. However, the Soviet leadership did not openly conflict with the Chinese authorities, giving priority to foreign relations. As a result, Soviet citizens in Xinjiang were held hostage to high politics. This affected the attitude of the new Soviet citizens - former subjects of the Russian Empire and Russian emigrants - to the USSR, and ultimately indirectly contributed to the weakening of the USSR's position in Western China.

\section{REFERENCES}

1. Ablazhey, N.N. (2007) S vostoka na vostok: Rossiyskaya emigratsiya v Kitae [From the East to the East: the Russian emigration in China]. Novosibirsk: SB RAS.

2. Krotova, M.V. (2014) SSSR i rossiyskaya emigratsiya v Man'chzhurii (1920-1930-e gg.) [The USSR and the Russian emigration in Manchuria, the 1920s-1930s]. St. Petersburg: Asterion .

3. Yakhimovich, S.Yu. (2015) Sovetskie grazhdane v Severnoy Man'chzhurii (1924-1935 gg.) [Soviet citizens in Northern Manchuria (1924-1935]. Khabarovsk: Ministry of Interior of Russia.

4. Voskresenskiy, A.D. (2004) Kitay i Rossiya v Evrazii: Istoricheskaya dinamika politicheskikh vzaimovliyaniy [China and Russia in Eurasia: Historical Dynamics of Political Interactions]. Moscow: Muravey.

5. Zolotarev, V.A. (1995) Protivostoyanie. Ocherki voenno-politicheskoy konfrontatsii pervoy poloviny XX veka [Confrontation. Essays on the militarypolitical confrontation of the first half of the twentieth century]. Moscow: [s.n.].

6. The Foreign Policy Archive of the Russian Federation (AVP RF). Fund 0253. List 1. File 1.

7. The Central Archive of the Federal Security Service of Russia. Fund 2. List 4. File 408.

8. The Foreign Policy Archive of the Russian Federation (AVP RF). Fund 054. List 4. P. 275 . File 4007.

9. The Foreign Policy Archive of the Russian Federation (AVP RF). Fund 054. List 5. P. 300 . File 5036.

10. The Foreign Policy Archive of the Russian Federation (AVP RF). Fund 0100. List 12. P. 153. File 59. 